„scryptoria”, powinno być: „skryptoria”. Na s. 404 (lin. 6 od dołu) jest: „stricte”, powinno być: „stricte” (to samo na s. 437, lin. 9 od dołu). Na s. 413 (lin. 12-13 od góry) jest: ,,apostołów Piotra i Pawła”, powinno być: ,apostołów Piotra i Jana” (por. z tekstem Dz 8, 14-24). Na s. 423 (lin. 5 od dołu) jest: „status quo ante”, powinno być: ,status quo ante” (tak jak na s. 83, lin. 4 od góry). Na s. 438 (lin. 1 od góry) jest: „Harmonia niezgodnych kanonów”, powinno być: „Harmonia niezgodnych kanonów" (tak jak na s. 439, lin. 15 od góry). Na s. 513 (lin. 2 i 7 od góry) jest: „San Apolinare”, powinno być: „San Apollinare”. Na s. 513 (lin. 9 od góry) jest: „Senigalli”, powinno być: „Senigallii”. Na s. 514 (lin. 1 od góry) jest: „Henryk IV I hrabina Matylda”, powinno być: „Henryk IV i hrabina Matylda”. Na s. 515 (lin 2 od góry) jest: „Genealogia Amalów”, powinno być: „Drzewo genealogiczne Amalów" (tak jak jest na s. 24 w tytule załączonej mapy).

Podsumowując, należy z naciskiem podkreślić, że narracja książki P. Heathera jest prowadzona w sposób niezwykle wciagający i rzeczowy. Autor „czaruje” Czytelnika nie tylko barwnym i miejscami dowcipnym językiem, dzięki czemu dużo łatwiej zapamiętać nawet szczegóły rozprawy, ale również licznymi ciekawymi hipotezami interpretacyjnymi, które są wynikiem wnikliwie przeprowadzonej hermeneutyki źródeł historycznych. Polski przekład dobrze oddaje te cechy oryginału, oferując jednocześnie Czytelnikowi kilka ciekawych ,uzupełnień", które wraz z bogatą szatą graficzną Odrodzenia Rzymu wręcz zachęcają do sięgnięcia po tę pozycję. Wydaje się również, że bardzo dobrym rozwiązaniem było zrezygnowanie z umieszczenia w Spisie treści tytułów podrozdziałów, które znalazły się praktycznie w każdym rozdziale książki. W ten sposób uzyskano klarowność i jasność Spisu, unikając tym samym niebezpieczeństwa natłoku drugorzędnych informacji.

W ostatecznym rozrachunku, pomimo znacznej ilości różnorodnych usterek, których nie udało się uniknąć polskiemu wydawcy najnowszej publikacji P. Heathera, warto tę pozycję polecić przede wszystkim entuzjastom historii starożytnego Rzymu i Bizancjum, historii powszechnej wieków średnich oraz historii Kościoła.

Damian Kalinowski - Lublin, KUL

\title{
Stanisław KALINKOWSKI, Scire Latine. Język taciński. Podręcznik dla alumnów i studentów teologii, Lingua Sacra 3, Warszawa 2014, Wydawnictwo „Verbinum”, ss. 370.
}

Dla humanistyki ostatnie lata w Polsce nie należały niestety do „lat thustych” w ogóle, a przedmiotów klasycznych w szczególności. Szkół nauczających klasycznego języka greckiego trzeba by szukać ze świeczką. $Z$ nauczania zaś łaciny, szkoły wycofywały się, gdyż był to dla nich kosztowny, a dla uczniów podobno jedynie nieprzydatny obowiązek. Według danych Ministerstwa Edukacji Narodowej, łaciny w Polsce uczy się ok. 1,5\% uczniów szkół średnich ogólnokształcących. 
Dla porównania w krajach Unii Europejskiej łaciny uczy się nadal 20-30\% tejże młodzieży. Nic więc dziwnego, że znajomość podstaw łaciny nie jest wymagana podczas rekrutacji na jakikolwiek kierunek studiów, ani na medycynę, ani na prawo, ani nawet na filologię klasyczna, gdyż na studia licencjackie na kierunku „,ilologia klasyczna" można zapisać się bez znajomości łaciny! Sic! Coraz częściej jest więc to przedmiot fakultatywny i jedynie od dobrej woli przyszłego lekarza lub prawnika zależy, czy zechce go w ogóle poznać. „Łacina jest matką nauki, ale skoro prawie nikt na maturze jej nie wybiera, nie ma sensu organizowanie egzaminu z tego przedmiotu. To niepotrzebne koszty" - stwierdził w opinii prof. Adam Hamrol, rektor Politechniki Poznańskiej i wiceprzewodniczący Konferencji Rektorów Akademickich Szkół Polskich, która 6 maja 2011 r. przyjęła uchwałę rekomendującą rezygnację z organizowania matury z łaciny w ogóle. Czyżby więc czekał nas całkowity zmierzch łaciny w Polsce? Czy jak bajka z bardzo, ale to bardzo, odległych czasów zabrzmią słowa polskiej szlachty z XVII wieku: Eques Polonus sum, Latine loquor? Albo też opinia, którą miał wygłosić znany angielski pisarz Daniel Defoe w 1728 roku: „Człowiek, który potrafi mówić po łacinie, może odbyć podróż z jednego końca Polski na drugi z taką łatwością, jak gdyby urodził się w tym kraju. Mój Boże! Cóż by uczynił dżentelmen, któremu by przyszło podróżować po Anglii, a który nie znałby żadnego języka prócz łaciny [...]. Nie mogę się nie użalić nad kondycją takowego podróżnika?" Oczywiście o mówieniu łaciną należy już dawno zapomnieć, ale może pozostała przynajmniej znajomość podstaw łaciny? Z nią niestety też nie jest najlepiej. Tli się jednak wciąż nadzieja i radość, że istnieją ludzie, którym wciąż się chce chcieć, którzy starają się pomimo przeciwnych działań bezdusznej biurokratycznej machiny ministerialnej kultywować znajomość języków klasycznych, którzy na wszelkie możliwe sposoby dobijają się do drzwi szkół z nauczaniem łaciny. Przed trzema laty, 13 czerwca 2011 roku, na portalu www.petycje.pl rozpoczęła się akcja zatytułowana Polska w Europie - Łacina w szkole zainicjowana przez dr. hab. Przemysława Nehringa, dr Barbarę Bibik i dr. Rafała Toczko z Katedry Filologii Klasycznej Uniwersytetu Mikołaja Kopernika, założycieli fundacji Traditio Europae, której celem jest promowanie języka łacińskiego i kultury antycznej. W petycji do byłej minister edukacji narodowej Katarzyny Hall postawili trzy postulaty: 1) możliwość rozpoczęcia nauki łaciny już w pierwszej klasie liceum; 2) zachowanie matury z łaciny i kultury antycznej zarówno na poziomie podstawowym, jak i rozszerzonym; 3) wprowadzenie języka łacińskiego do szkół gimnazjalnych, być może jako drugiego języka obcego do wyboru. Pojawiły się pierwsze sukcesy - zapadła decyzja, że jednak łacina pozostanie na maturze w roku 2015. Mimo to w szkołach łacina zanika. Język jest fakultatywny i ma sporą konkurencję w postaci języków nowożytnych. W olimpiadach z języka łacińskiego z roku na rok bierze udział coraz mniej osób. A tymczasem wokół nas pojawia się coraz więcej błędnego używania języka łacińskiego - żeby wspomnieć o najczęstszym chyba, i dla klasyka aż świdrującym w uchu, błędnym akcentowaniu tak często, ostatnio przypominanej, lekarskiej zasady: primum non nocēre! Na samogłoskę 
„o" namiętnie akcentują dziennikarze, publicyści, a i młodsi następcy Hipokratesa również. Takich problemów nie byłoby, gdyby zgłębili choćby podstawy łaciny.

$\mathrm{Z}$ tym większą radością przychodzi powitać na rynku księgarskim i w dydaktyce w Polsce pozycję autorstwa człowieka, któremu wciąż się chce chcieć, który od ponad 30 lat praktycznie naucza języków klasycznych i który jest niestrudzonym propagatorem kultury grecko-łacińskiej (vide jego książki: Anegdoty Greków i Rzymian, Warszawa 2005; Aurea dicta, Warszawa 1999-2001) oraz nieocenionym tłumaczem dzieł pisarzy wczesnochrześcijańskich, przede wszystkim Orygenesa. A mowa jest oczywiście o dr. Stanisławie Kalinkowskim i jego najnowszym dziele Scire Latine, które ukazało się w styczniu 2014 roku - jako trzeci tom w serii Lingua Sacra wydawnictwa VERBINUM, przygotowywanej we współpracy z Bractwem Słowa Bożego. Warto podkreślić, że nie jest to pierwszy podręcznik autorstwa S. Kalinkowskiego. Autor - jako doświadczony pedagog - przygotował już podręcznik do nauki języka łacińskiego dla studentów prawa (we współpracy z prof. dr. hab. Jerzym Andrzejem Wojtczakiem-Szyszkowskim: Iure et Legibus, Warszawa 2000, 2005²) oraz podręcznik do nauki języka greckiego ('E $\lambda \lambda \eta v \imath \sigma \tau i$

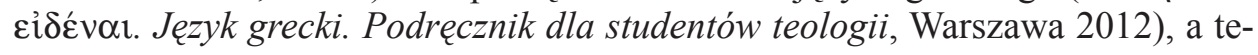
raz oddaje nam do rąk podręcznik do języka łacińskiego, przygotowany głównie z myślą o alumnach i studentach teologii, biblistyki i prawa kanonicznego.

Autor, który jest doświadczonym i utalentowanym dydaktykiem języka łacińskiego, stworzył podręcznik spełniający wszelkie wymogi stawiane tego typu książkom. Podręcznik jest skonstruowany logicznie oraz jest przejrzysty w układzie i w treści. Składa się z trzech zasadniczych części: pierwszą jest kurs języka łacińskiego, który obejmuje 28 jednostek lekcyjnych, na które składa się materiał gramatyczny, zasadniczo oryginalne teksty, paremie i przysłowia łacińskie, sentencje i zwroty łacińskie oraz ćwiczenia. Część drugą podręcznika stanowią wypisy z Pisma Świętego, tekstów wczesnochrześcijańskich i średniowiecznych pisarzy kościelnych, fragmenty poezji chrześcijańskiej oraz inne teksty i dokumenty (jak np. kanony soborów, reguła benedyktyńska, reguła św. Franciszka, dokumenty papieskie, modlitwy). Na część trzecią składają się: wykaz ksiag biblijnych, częściej spotykane łacińskie zwroty i skróty, indeksy oraz nieodłączny słownik łacińsko-polski.

Zarówno dla dydaktyka, jak i dla studenta, z pewnością najważniejsza jest część pierwsza podręcznika. Bezsprzecznie ogromną wartością poszczególnych jednostek lekcyjnych są napisane prostym i klarownym językiem wyjaśnienia zagadnień gramatycznych (co przy dzisiejszej nieznajomości przez większość studentów podstaw gramatyki języka polskiego jest szczególnie karkołomne!). Co więcej, bardzo często Autor umieszcza w tych wyjaśnieniach swoiste smaczki gramatyczne - bardzo przydatne niuanse, które czasami trudno znaleźć w suchych opracowaniach gramatyk. Inną godną podkreślenia cechą jednostek lekcyjnych jest dobór tekstów, które operują tylko zagadnieniami gramatycznymi już poznanymi przez studentów - co świadczy o ogromnym doświadczeniu pedagogicznym Autora - a co nie jest powszechne w innych podręcznikach do nauki 
języka łacińskiego. Również ćwiczenia proponowane jako podsumowanie lekcji i utrwalenie omówionego materiału gramatycznego, nie są przeładowane (co zdarza się w niejednym podręczniku - nawet dla uczniów szkół średnich - vide: Porta latina, red. S. Wilczyński - E. Pobiedzińska - A. Jaworska, Warszawa 2005), co pozostawia pole manewru dla prowadzącego lektorat i pozwala zwrócić uwage studentów na kwestie najistotniejsze w przyswajaniu łaciny. Pomocą w tym są wyraźne tabele odmian - bez pominięć, $\mathrm{z}$ wytłuszczonymi końcówkami gramatycznymi (jakby twórcy innych podręczników i gramatyk dbali o minimalne zużycie farby drukarskiej...). Rękę doskonałego dydaktyka i długoletniego praktyka widać również w rozkładzie materiału - wystarczy jeden przykład: większość podręczników traktuje liczebniki po macoszemu, umieszczając je w jednej $\mathrm{z}$ ostatnich jednostek lekcyjnych. $\mathrm{Z}$ reguły nie wystarcza już czasu na dokładne omówienie tej partii materiału, więc liczebniki oraz związaną z tym rachubę lat i kalendarz omawia się ,po łebkach”, a przecież tak naprawdę to właśnie z liczebnikami łacińskimi i kalendarzem zgłębiający podstawy języka łacińskiego będą mieli najwięcej do czynienia. Korzystający z podręcznika dr. Kalinkowskiego z pewnością nie będą używać przysłowiowego „po pierwsze primo”. Omawiana publikacja adresowana jest do studentów teologii i dlatego uwzględnia przede wszystkim słownictwo z tej dziedziny, co jest również niezwykle ważne i pomocne, a teksty - dotykające tej tematyki - są starannie dobrane i nie za długie. $\mathrm{W}$ pierwszej części położony jest w nich nacisk na zastosowanie omawianych zagadnień gramatycznych, a w drugiej na doskonalenie umiejętności tłumaczenia tekstów jednolitych, stanowiących pewną całość i zawierających różne zagadnienia gramatyczne. Nauczyciel może więc sam - w pozostałym czasie - dobrać teksty źródłowe po zrealizowaniu zasadniczej partii materiału. Ostatnią rzecz, na którą chciałbym zwrócić uwagę, niektórzy może zaliczą to do minusów tego podręcznika, ja jednak uważam - nie wiedząc czy jest to zabieg celowy Autora czy też felix culpa - że jest to rzecz dająca możliwość poszerzenia horyzontów naukowych studentów i zdobycia kolejnej sprawności. A chodzi mi o teksty źródłowe z części drugiej podręcznika. Liczne, specjalistyczne słówka zawarte w tych tekstach nie są umieszczone w słowniku z końca książki. Niektórzy może będą utyskiwać, że trzeba będzie nosić słowniki, że trzeba będzie po wielokroć powtarzać formy podstawowe i znaczenie... Niech utyskują! Sapienti sat! W świecie, w którym jedynym słownikiem używanym przez młodzież jest słownik w komputerze służący do sprawdzania pisowni, nauczenie korzystania ze słownika (a nie jest to łatwe i oczywiste dla znacznej części studentów!) jest ze wszech miar pożądane. Będzie to także okazja do zaprezentowania istniejących słowników, a nie bazowanie tylko na słowniku minimum, jakim jest ten zawarty na ostatnich stronicach podręcznika. Godny podkreślenia jest także fakt, że podręcznik wydrukowany został bezbłędnie, co świadczy i o Autorze, i o wydawnictwie, które podjęło się wydawania serii Lingua Sacra.

Niestety, podręcznik ten ze wszystkimi swymi ,plusami dodatnimi”, cytując szeroko znanego, ma też swoje ,plusy ujemne”, czy też odwołując się do klasyka 
mniej znanego: „nie jest to jednak opus perfectum” - przynajmniej w oczach piszącego te słowa. Nie chodzi mi o błędy, ale raczej drobne dyskusyjne kwestie, na które zwracam uwage jako człowiek, który jeszcze niedawno sam studiował język łaciński, a obecnie próbuje go nauczać. Od dawna postuluję, aby od początku nauki łaciny wprowadzić nauczanie pełnych form czasownikowych (umieszczać je w małych słownikach pod czytankami). Wiem, jak trudne jest „douczanie się” form perfektum czy supinum, gdy ma się już opanowane dwie pierwsze formy czasownikowe. Nie trzeba wtajemniczać i mącić w głowach na pierwszej lekcji, czym te formy sa, ale wprowadzenie do nauki od początku wszystkich form czasowników ułatwiłoby naukę. Drugą kwestią jest sztywne trzymanie się wykazu liczebników, które powtarza się w każdym podręczniku i w każdej gramatyce opisowej języka łacińskiego. Studenci nie mają z reguły problemów z liczebnikami pełnymi $(30,90,100)$. Problemy zaczynają się, gdy trzeba napisać i powiedzieć: 99, 129, 999 itd. Umieszczenie kilku tego typu liczebników w tabeli zbiorczej ułatwiłoby studentom naukę tworzenia liczebników i ewentualną pracę samodzielną z podręcznikiem. Warto również pomyśleć o zamieszczeniu w kolejnych wydaniach słownika minimum polsko-łacińskiego (w którym należałoby umieścić przynajmniej najważniejsze słowa i te konieczne do wykonania ćwiczeń translatorskich z polskiego na łacinę zawartych w podręczniku), który pozwoliłby na uczenie się słówek właśnie w kierunku od języka ojczystego do obcego, co - jak pokazuje praktyka dydaktyczna - przynosi szybsze i trwalsze efekty. Powyższe uwagi nie wskazują jak wspomniałem, na rażące i oczywiste błędy, ale są raczej postulatami do rozważenia przy kolejnych wznowieniach tego doskonałego podręcznika.

Pozostaje na koniec serdecznie zachęcić do korzystania z podręcznika autorstwa dr. Stanisława Kalinkowskiego, do sięgnięcia po niego dla nauki pięknego języka Cycerona i Kościoła, a może dla przypomnienia sobie i odświeżenia deklinacji, koniugacji, ablatiwu absolutu, koniunktiwów..., a przede wszystkim pozostaje złożyć podziękowania i oddać hołd temu, który docere Latinam auso, który - wbrew ludziom powtarzającym, że łacina to język martwy, że nie warto się nim zajmować, wbrew tym wyrzucającym łacinę ze szkół i programów - wciąż ukazuje piękno języka łacińskiego i wskazuje: praeclarum est scire Latine!

Ks. Marcin Wysocki - Lublin, KUL

\section{Ks. Mariusz SZRAM, Cnota pokory w nauczaniu greckich Ojców Kościoła IV wieku, Lublin 2014, Wydawnictwo KUL, ss. 252.}

W chrześcijańskiej teologii moralnej i teologii duchowości, a także w kaznodziejstwie wiele mówi się ostatnio o konieczności nabywania cnoty pokory. Do jej praktykowania wzywa często obecny papież Franciszek. Monografia ks. M. Szrama, znanego patrologa z Katolickiego Uniwersytetu Lubelskiego Jana Pawła II, włącza się twórczo w ten nurt nauczania Kościoła i dostarcza ważnych argumentów ze strony wczesnochrześcijańskich mistrzów duchowych. 